\title{
PEMBELAJARAN SAINS BERBASIS SAINSTIFIK BAGI GURU SMK
}

\author{
Sujarwo \\ Universitas Muslim Nusantara [UMN] Al-Washliyah
}

\begin{abstract}
ABSTRAK
Pembelajaran di sekolah bagi siswa usia sekolah menengah atas menantang bagi siapa saja yang menjadi leadernya di kelas. Kemampuan menguasai kelas adalah salah satu faktor kesuksesan guru yang mengelolanya melalui penyampaian materi pelajaran, tentunya dengan segala persiapan. Sains merupakan mata pelajaran yang proses pembelajarannya tidak harus dikelas saja melainkan proses pembelajarannya dapat dilakukan diluar kelas. Tujuan kegiatan adalah untuk memberikan pemahaman mengenai pembelajaran sains bagi guru SMKN 1 Kecamatan Teluk Mengkudu. Kegiatan pelatihan dan/atau sosialisasi yang telah dilakukan diikuti oleh sembilan belas guru. Guru melaksanakan pembelajaran dengan menerapkan pembelajaran sainstifik akn memberikan pengalaman kepada siswa dan terciptanya kondisi yang memungkinkan terbentuknya karakter seperti jujur, memiliki rasa ingin tahu dan disiplin. Dengan deimkian, diharapkan kegiatan ini memberikan inspirasi dan stimulasi bagi guru dengan memupuk dan menjaga keterlibatan siswa dalam proses pembentukan karakter sehingga nilai-nilai yang harapkan pada diri siswa menjadi suatu kebanggaan institusi maupun suatu bangsa.
\end{abstract}

Kata Kunci: Sains, Usia Sekolah Menengah Atas, Sainstifik

\begin{abstract}
ABSTRACK
School learning for high school-age students is challenging for those who are leaders in the class. The ability to master the class is one of the factors of the success of the teacher who manages it through the delivery of subject matter, of course in all preparations. Science is a subject whose learning process does not have to be classy but the learning process can be done outside the classroom. The purpose of the activity is to provide an understanding of science learning for teachers of SMK 1 in Teluk Mengkudu District. The training and / or outreach activities carried out were attended by nineteen teachers. The teacher carries out learning by applying scientific learning to provide experience to students and the creation of conditions that enable character formation such as honesty, curiosity and discipline. With deimkian, it is hoped that this activity provides inspiration and stimulation for teachers by fostering and maintaining student involvement in the process of character building so that the values expected by students become a pride of institutions and a nation.
\end{abstract}

Keyword: Science Learning, High School Age

\section{PENDAHULUAN}

Pembelajaran di sekolah bagi siswa usia sekolah menengah atas menantang bagi siapa saja yang menjadi leader-nya di kelas. Kemampuan menguasai kelas adalah salah satu faktor kesuksesan guru yang mengelolanya melalui penyampaian materi pelajaran, tentunya dengan segala persiapan. Artinya, model, strategi maupun metode yang diterapkan guru tidak hanya terpaku pada satu model, strategi atau metode saja melainkan guru harus mampu memaksimalkan proses pembelajaran yang akan terjadi dengan menerapkan model, strategi dan metode bervariasi. Hal ini dilakukan agar siswa usia sekolah mengenah atas tidak cepat merasakan kejenuhan, bosan dan sebagainya. Seperti halnya di sekolah menengah atas kejuruan yakni Sekolah Mengah Kejuruan [SMK] Negeri 1 Teluk Mengkudu Kecamatan Sialang Buah Kabupaten Serdang Bedagai. Pelajaran-pelajaran yang memerlukan penerapan model, strategi dan metode yang membuat siswa tidak segera jenuh dan bosan 
adalah seluruh mata pelajaran yang dipelajari siswa di sekolah. Namun dari beberapa mata pelajaran yang sangat perlu ditekankan salah satunya adalah mata pelajaran terkait sains. Sebagaimana diketahui bahwa, sains merupakan mata pelajaran yang proses pembelajarannya tidak harus dikelas saja melainkan proses pembelajarannya dapat dilakukan diluar kelas yang disesuaikan dengan pembahasan, sumber belajar, model, strategi dan metode yang akan diterapkan serta karakter yang hendak dicapai. Jika hal dapat dilaksanakan dengan baik maka proses pembelajaran yang terjadi akan memberikan dampak bagi peningkatan pemahaman siswa terhadap materi yang telah disampaikan. Kemampuan mengingat siswa akan semakin baik seiring dengan adanya pemicu ingatan yaitu pengalaman proses pembalajaran yang telah dilakukan dengan mengkombinasikan sumber belajar, lingkungan, model, strategi atau metode yang diterapkan. Namun demikian, guru-guru masih merasakan kesulitan dalam menyampaikan materi pelajaran khususnya mata pelajaran sains. Kesulitan yang dihadapi adalah siswa usia sekolah menengah atas ketika proses pembelajaran berlangsung masih saja ada siswa yang merasa bosan dan jenuh untuk belajar sehingga kelihatan enggan untuk memperhatikan, mendengarkan dan memahami materi yang disampaikan guru. Padahal, proses belajar yang pernah terjadi adalah proses belajar yang memanfaatkan segala sesuatu yang bisa dijadikan sebagai sumber belajar tetapi memang yang menjadi kelemahannya adalah adalah tahapan-tahapan yang dilakukan masih belum jelas ketika dilakukan.
Untuk itu, perlu dilakukan pendekatan pembelajaran yang memiliki tahapan pembelajaran sehingga sangat berkonstribusi bagi peningkatan pemahaman.

Berdasarkan analisis situasi di atas menunjukkan bahwa yang menjadi permasalahan mitra adalah guru-guru masih melihat dan/atau merasakan bosan, jenuh dan kesulitan lain sehingga guru merasakan kesulitan dalam menyampaikan materi pelajaran khususnya mata pelajaran terkait sains. Untuk itu, perlu dilakukan pendekatan pembelajaran dalam bentuk pelatihan dan/atau sosialisasi pembelajaran sains berbasis sainstifik bagi guru dan peningkatan pemahaman siswa.

Oleh karena itu, yang menjadi tujuan pelaksanaan kegiatan ini adalah untuk memberikan pemahaman mengenai pembelajaran sains khususnya bagi guru SMKN 1 Kecamatan Teluk Mengkudu.

\section{METODE PELAKSANAAN}

Untuk memahamkan guruguru mengenai pembelajaran sains bagi anak usia sekolah menengah atas berbasis sainstifik adalah dengan melakukan pelatihan dan/atau sosialisasi kepada guru-guru melalui tutorial yang didukung dengan simulasi sainstifik. Tutorial dilakukan oleh tim pelaksana kegiatan sedangkan simulasi dilakukan oleh guru-guru peserta kegiatan dengan melaksanakan tahapan-tahap sebagai berikut:

a. Tim mempersiapkan meja registrasi didepan ruang lokasi kegiatan;

b. Tim pelaksana memberikan kesempatan kepada guru-guru untuk mengikuti kegiatan penyuluhan dengan cara mendaftarkan diri ke meja 
pendaftaran yang telah disediakan tim di depan ruang lokasi kegiatan;

c. Tim merekapitulasi guru-guru yang telah mendaftar untuk menjadi peserta kegiatan;

d. Tim mempersilahkan guru-guru memasuki ruang dan menempati tempat duduk yang telah disediakan;

e. Setelah guru-guru dan tim pelaksana telah siap untuk melaksanakan kegiatan, selanjutnya pembukaan kegiatan yang diawali oleh pembawa acara dan dibuka oleh perwakilan sekolah mengenah atas;

f. Tim melaksanakan tutorial kepada guru-guru;

g. Tim mempersiapkana segala kebutuhan untuk keperluan simulasi;

h. Guru-guru melakukan simulasi berdasarkan materi tutorial yang telah disampaikan tim;

i. Tim pelaksana mengobservasi dan memberikan evaluasi kepada guru-guru;

j. Setelah simulasi selesai, tim memberikan evaluasis secara komprehensif bagi guru-guru;

k. Kegiatan ditutup oleh perwakilan sekolah atau tim pelaksana.

Subjek dalam kegiatan adalah guruguru SMKN 1 Kecamatan Teluk Mengkudu dengan posisi:

1) Sebagai sasaran kegiatan peningkatan kompetensi;

Kegiatan ini ditujukan untuk peningkatan kompetensi guruguru sekolah menengah atas;

2) Sebagai peserta pelatihan dan/atau sosialisasi;

3) Sebagai sumber informasi dan/atau data eksistensi mitra.

\section{HASIL DAN PEMBAHASAN}

Kegiatan pelatihan dan/atau sosialisasi yang telah dilakukan diikuti oleh sembilan belas guru. Guru-guru yang menjadi peserta kegiatan adalah semua guru yang melaksanakan tugasnya di SMK N 1 Kecamatan Teluk Mengkudu. Proses kegiatan mendapat respon yang baik dari guru-guru peserta kegiatan. Mereka menunjukkan sikap antusias dalam mengikuti kegiatan dari awal kegiatan sampai akhir kegiatan. Respon positif ditunjukkan guruguru sehingga memicu terjadinya diskusi yang panjang terkait materi yang disampaikan saat proses kegiatan berlangsung sehingga suasana kegiatan terasa tampak hidup dan kondisi kundusif serta komunikasi dua arah terjadi sebagaimana mestinya. Hal seperti inilah yang diharapkan terjadi ketika guru-guru melaksanakan pembelajaran di kelas bersama para siswanya. Menjaga keterlibatan peserta didik dalam proses pembelajaran dengan menerapkan kaidah sainstifik sangat penting. Keterlibatan yang terjadi tidak hanya keterlibatan secara psikis saja melainkan keterlibatan peserta didik secara totalitas sehingga menghindarkan dari kondisi peserta didik dari situasi bosan, jenuh, ngantuk dan sebagainya.

Langkah-langkah pembelajaran sainstifik yang dapat diterapkan guru adalah seperti pada gambar di bawah ini:

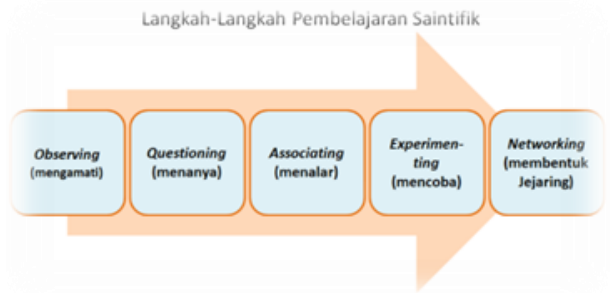

Gambar 1. Langkah-langkah pembelajaran sainstifik 
Hal-hal yang menjadi diskusi ketika proses pembelajaran lebih difokuskan pada materi pelatihan dan/atau sosialisasi yakni pembelajaran sains bagi anak usia sekolah menengah atas. Materi yang disampaikan seputar hakikat sains dan pembelajaran sains. Dengan demikian, setiap guru yang melaksanakan pembelajaran dengan menerapkan kaidah sainstifik memberikan pengalaman dan terciptanya kondisi yang memungkinkan terbentuknya karakter bagi anak usia sekolah menengah seperti jujur, memiliki rasa ingin tahu, disiplin dan sebagainya. Hal ini sejalan yang disampaikan Mundilarto (2013) dalam artikelnya yang berjudul "membangun karakter melalui pembelajaran sains" yang menyatakan bahwa nilai-nilai dalam pendidikan karakter diantaranya adalah religius, jujur, disiplin, rasa ingin tahu, kerja keras, mandiri dan sebagainya. Ketika guru melaksanakan pembelajaran dengan menerapkan kaidah sainstifik, menunjukkan, guru berkesempatan besar dalam menerapkan dan menginformasikan konsep sains kepada siswanya yang secara tidak langsung mengajak siswanya untuk melakukan berfikir tingkat tinggi dan pada akhirnya akan menuju pada pencapaian pemahaman. Hal ini sejalan dengan Kaniwati (2017) dan Fitriyati dkk (2017).

\section{KESIMPULAN}

Berdasarkan uraian di atas maka dapat disimpulkan bahwa:

a. Kegiatan pengabdian kepada masyarakat dengan cara pelatihan dan/atau sosialisasi kepada guru-guru SMK N 1 Kecamatan Teluk Mengkudu. b. Pelaksanaan kegiatan ini dihadiri oleh sembilan belas guru yang merupakan peserta kegiatan termasuk wakil Kepala Sekolah SMK Negeri 1 Teluk Mengkudu Kecamatan Sialang Buah;

c. Kegiatan inti yang dilaksanakan 30 November 2016 diharapkan memberikan inspirasi dan stimulasi bagi guru dalam melaksanakan pembelajaran dengan memupuk dan menjaga keterlibatan peserta didik agar terjadi pengalaman dan proses pembentukan karakter sehingga nilai-nilia yang harapkan pada diri peserta didik menjadi suatu kebanggaan sekolah dan suatu bangsa.

\section{REFERENSI}

Rukim, Urip. 2014. Model Pembelajaran Saintifik 19 Mata Pelajaran di SMA/MA. Available online: https://urip.wordpress.com/201 4/01/07/model-pembelajaransaintifik-19-mata-pelajaran-dismama/. Diunduh 18 Maret 2017.

Mundilarto. 2013. Membangun Karakter Melalui Pembelajaran Sains. Jurnal Pendidikan Karakter. No. 2, Juni Tahun 2013. Available online: https://journal.uny.ac.id/index. php/jpka/article/view/1436/122 4.

Kaniawati, Ida. 2017. Pengaruh Simulasi Komputer Terhadap Peningkatan Penguasaan Konsep Impuls-Momentum Siswa SMA. Jurnal Pembelajaran Sains Vol. 1 No. 1 Agustus 2017. Available online: 
http://journal2.um.ac.id/index.p hp/jpsi/article/download/637/7

90.

Fitriyat, Ida. Hidayat, Arif. Munzil. 2017 Pengembangan Perangkat Pembelajaran Ipa Untuk Meningkatkan Kemampuan Berpikir Tingkat Tinggi Dan Penalaran Ilmiah Siswa Sekolah Menengah Pertama. Jurnal Pembelajaran Sains Vol. 1 No. 1 Agustus 2017. Available online: http://journal2.um.ac.id/index.p hp/jpsi/article/download/651/7 91.

Meiningdias, Catur Yoga. 2015. KB I Pendekatan Saintifik dalam Pembelajaran. Availabale online: http://www.caturyogam.info/20 15/08/kb-i-pendekatansaintifik-dalam.html 